\title{
Pembinaan Sapta Usaha Peternakan Kambing Jawarandu Desa Pambon, Brondong, Kabupaten Lamongan
}

\author{
Usman Ali', Rois Arifin ${ }^{2}$ \\ ${ }^{1}$ Jurusan Peternakan, Fakultas Peternakan, ${ }^{2}$ Jurusan Manajen, Fakultas Ekonomi \\ ${ }^{1,2}$ Universitas Islam Malang \\ e-mail: ${ }^{1}$ usmanchalim@gmail.com
}

\begin{abstract}
Abstrak
Program Kemitraan Masyarakat (PKM) ini bertujuan untuk meningkatkan pengetahuan dan keterampilan peternak kambing dalam berbagai aspek produksi dan manajemen peternakan sistem intensif mengacu pada sapta usaha peternakan. Target khusus program PKM adalah peternak kambing dapat memanfaatkan limbah agroindustri lokal (ampas tahu, kulit daging kelapa, tongkol jagung ampas kecap dan bekatul) yang difermentasi untuk meningkatkan kualitas pakan sebagai pakan konsentrat serta melakukan reboisasi untuk menjaga lingkungan yang asri dengan penanaman sistem tiga strata (STS) pada lahan pertanian dan menggunakan pupuk organik dari kotoran kambing. Untuk pencapaian tujuan dan target PKM, maka tim pengabdi menggunakan berbagai metode yaitu penyuluhan, pelatihan dan demo pembuatan fermentasi dan formulasi limbah agroindustri sebagai pakan konsentrat dan model penanaman STS, pembinaan dan pendampingan usaha. Program PKM ini direspon peternak kambing yang proaktif dalam semua kegiatan penyuluhan, pelatihan dan pelatihan fermentasi pakan dan pendampingan usaha. Sebelumnya peternak kambing memberikan pakan hijauan digantung, maka dengan dibuatkan palungan dan bantuan mesin copper, maka pemberian hijauan dicacah dahulu dan dimasukkan dalam palungan sehingga pakan tidak tercecer dan lebih efisien. Selain itu dibantu kambing pejantan unggul dari luar mengurangi inbreeding. Selanjutnya peternak mengaplikasikan ilmu yang diperoleh dengan memperbaiki manajemen produksi peternakan kambing sistem intensif yang menggunakan bahan pakan lokal dari limbah agroindustri yang difermentasi dahulu agar lebih berkualitas, bergizi dan palatabel yang dapat meningkatkan produktifitas ternak kambing sehingga pendapatan dan keuntungan peternak bertambah. Luaran program PKM ini adalah metode fermentasi pakan, formulasi pakan konsentrat dari limbah agroindustri lokal, model penanaman sumber hijauan dalam STS dan artikel jurnal pengabdian masyarakat ISSN. Kesimpulan program PKM ini yaitu peternakan kambing menuju intensif dan mengacu pada sapta usaha peternakan.
\end{abstract}

Kata kunci : kambing jawarandu; manajemen produksi; STS; sapta usaha peternakan

Abstract

This Community Partnership Program (CPP) aims to increase the knowledge and skills of goat breeders in various aspects of production and management of intensive livestock systems referring to livestock business enterprises. The specific target of the CPP) program is that goat farmers can utilize local agroindustrial waste (tofu pulp, coconut meat skin, fermented soy sauce and rice corn cobs) to improve feed quality as concentrate feed and reforestation to maintain a beautiful environment by planting three strata systems (STS) on agricultural land and using organic fertilizer from goat manure. To achieve CPP goals and targets then the service team used various methods, namely counseling, training and demonstration of making fermentation and formulation of agro-industrial waste as feed concentrates and models of STS planting, coaching and business assistance. This CPP program was responded to by goat farmers who were proactive in all extension activities, training and training in feed fermentation and business assistance. Previously, goat breeders provided forage feeds to be hung, then by making manger and copper machine assistance, the forage was chopped first and put in a manger so that the feed was not scattered and more efficient. In addition, assisted by superior male goats from outside reduce inbreeding. The conclusion of this CPP program is that goat farming is intensive and refers to livestock farming business. Furthermore, breeders' knowledge is gained by improving the management of intensive production systems that use high quality, nutritious and palatable ingredients which can increase the productivity and income of farmers. increase. The output of this PKM program is feed fermentation method, concentrate feed formulation from local agroindustry waste, a model of the forage source planting in the STS and ISSN community service journal article. The conclusion of this PKM program is that goat farming is intensive and refers to livestock farming business.

Keywords: jawarandu goats; production management; STS; farm business sapta 


\section{PENDAHULUAN}

Mitra program PKM ini adalah kelompok peternak kambing Jawarandu di Desa Pambon, Brondong Kabupaten Malang, dengan profil peternakannya masih tradisional dalam kandang sederhana dengan lantai tanah padat dibuat lebih tinggi dari sekitarnya yang dialasi geladakan belahan kayu bambu dan diatasnya sisa hijauan pakan. Pemberian pakan hijauan meliputi rumput lapang, tanaman ramban, leguminosa dan daun semak pahitan yang tumbuh liar di pinggir jalan, lahan kosong dan pagar. Peternak belum membudidayakan hijauan pakan unggul seperti rumput gajah, lamtoro, gamal dan kaliandra dengan baik.

Kambing jarang diberikan comboran konsentrat sesekali dicombor bekatul plus garam sehingga pakan yang dikonsumsi belum memenuhi kebutuhan nutrisi sehingga produktivitas masih rendah. Kambing jawarandu merupakan hasil persilangan kambing peranakan etawah dan kambing kacang dengan sifat fisik kambing kacang lebih dominan, cepat berkembangbiak, prolifik, pertumbuhan dan produksi karkas tinggi bahkan kualitas daging berlemak disukai konsumen sebagai masakan gule dan sate diyakini dapat meningkatkan stamina kejantanan. Ditinjau dari sisi gizi pakan, kambing mampu mentolerir pakan berserat kasar lebih $15 \%$ dan protein kasar kurang 14\% [2]. Apabila manajemen pemeliharaan kambing secara intensif, maka berpeluang sebagai bisnis ternak potong yang laris manis karena harga kambing relatif murah dan terjangkau bagi masyarakat ekonomi menengah ke bawah.

\section{SUMBER INSPIRASI}

Pengendalian aspek produksi dalam usaha peternakan kambing meliputi pemilihan bibit dan bakalan kambing, pemberian pakan, pemeliharaan dan perkandangan, sistem reproduksi, pencegahan penyakit dan pemasaran sudah dilakukan dengan baik, namun ada beberapa faktor yang belum dikuasai dengan benar. Hal inilah yang menjadi permasalahan yang dihadapi peternak kambing dan dicari solosinya bersama.
Kambing dikandangkan sistem koloni tanpa dipisahkan antara pejantan, induk, dara dan anakan. Hal ini menimbulkan banyak resiko yaitu ternak sering berkelai, berebut pakan, perkawinan inbreeding, pemacek tidak unggul dan mengganggu induk bunting. Khusus kambing jantan dewasa seharusnya diikat dalam petak tersendiri dan dikeluarkan untuk keperluan pemacek dalam perkawinan atau dimandikan. Pemberian pakan hijauan masih digantung tidak puya palungan dan tidak dicacah sehingga pakan banyak tercecer dn tidak efisien. Pakan konsentrat yang diberikan mono bahan bekatul seharusnya dikombinasi dengan bahan pakan lain dari limbah organik yang masih layak untuk kambing seperti limbah kulit daging kelapa dan ampar tahu dan lainnya dan limbah bahan perlu difermentasi supaya kualitas pakan meningkat dan bergizi.

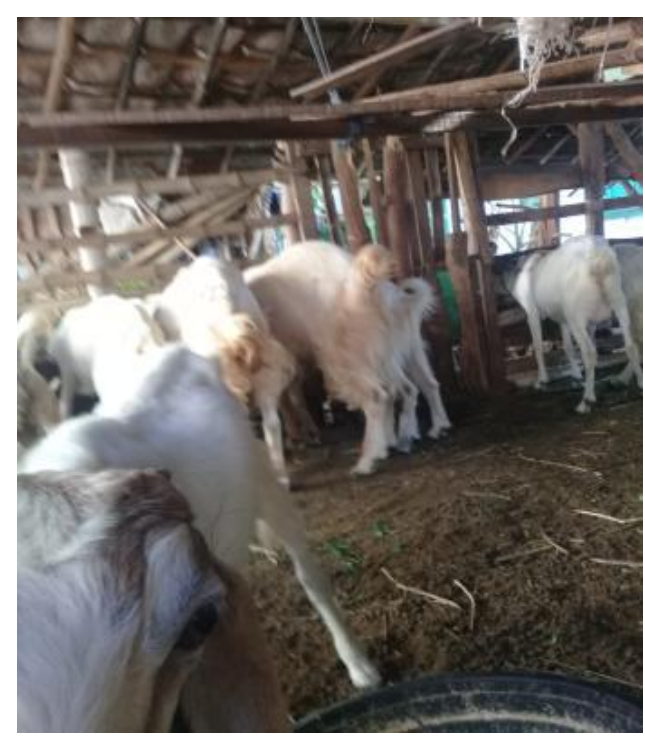

Gambar 1. Kondisi kandang kambing

\section{METODE KEGIATAN}

Untuk merealisasikan program PKM ini, tim pengusul menggunakan beberapa metode pendekatan meliputi observasi di lapang, wawancara dengan peternak, penyuluhan tentang sapta usaha peternakan [3] dan pembinaan usaha, demoplot pembuatan pakan konsentrat, pelatihan pengolahan fermentasi pakan dan formulasi pakan dan pengomposan limbah ternak, uji coba produk 
pakan kambing, mengenalkan alat copper untuk efisiensi pakan, bantuan pejantan unggul untuk mengurangi inbreeding, selanjutnya melakukan konsultasi dan pendampingan usaha peternakan kambing.

\section{KARYA UTAMA}

Kegiatan utama dalam program PKM ini meliputi penyuluhan sapta usaha peternakan dan manajemen produksi, pelatihan pembuatan pakan fermentasi dari limbah agroindustri lokal, reboisasi sekitar kandang dan penanaman sistem tiga strata (STS) di lahan pertanian dan pendampingan usaha dan konsultasi peternakan. Dalam tahap penyuluhan, tim pengabdi telah mempersiapkan materi penyuluhan tentang manajemen produksi dan pendalaman sapta usaha peternakan kambing yang meliputi pemilihan bakalan kambing yang baik, strategi pemberian pakan kambing meliputi hijauan dan konsentrat, manajemen kandang dan pemeliharaan, penanganan reproduksi dan perkawinan ternak, pencegahan dan pengobatan penyakit serta sistem pemasaran produk ternak [1]. Selain itu dilakukan diskusi permasalahan yang dihadapi dan diintroduksi metode fermentasi dan formulasi pakan konsentrat kambing dari campuran bahan limbah kulit daging kelapa pengganti bungkil kopra, ampas kecap, bekatul dan ampas tahu yang harga murah, kemudian diformulasi dicampur konsentrat pabrik.

Penyampaian materi penyuluhan ini disertai diskusi guna mengevaluasi minat peternak terhadap materi penyuluhan dan tukar pengalaman teoritis pengendalian produktivitas ternak antara tim pengabdi dengan peternak mitra. Penyuluhan dilakukan secara massal dan dilanjutkan secara individu pada saat kunjungan lapang untuk memberikan bimbingan dan konsultasi secara personal. Penyuluhan dilakukan dengan cara ceramah dan tanya jawab serta sharing pengalaman peternak dengan teori usaha peternakan. Kegiatan ini direspon cukup baik dan telah dibentuk kelompok peternak kambing baik untuk kambing qurban, aqiqohan, hajadan masyarakat serta ada yang dipasarkan bebas. Sebelumya pemberian hijauan pakan digantungkan di dinding kandang belum ada tempat pakan khusus palungan, kemudian peternak dibantu pembuatan palungan dan mesin copper agar pemberian pakan efisien tidak banyak tercecer. Jumlah pemberian hijauan pakan sebaiknya maksimal 10\% bobot badan kambing [4]. Hasil kunjungan di kandang menunjukkan bahwa kandang sudah dilengkapi palungan tempat pakan dari kayu yang rapat sehingga sekaligus untuk tempat pemberian pakan konsentrat sehingga tidak banyak yang tercecer, selain itu peternak sudah mencacah hijauan pakan sehingga memudahkan kambing mengkonsumsi pakan hijauan..

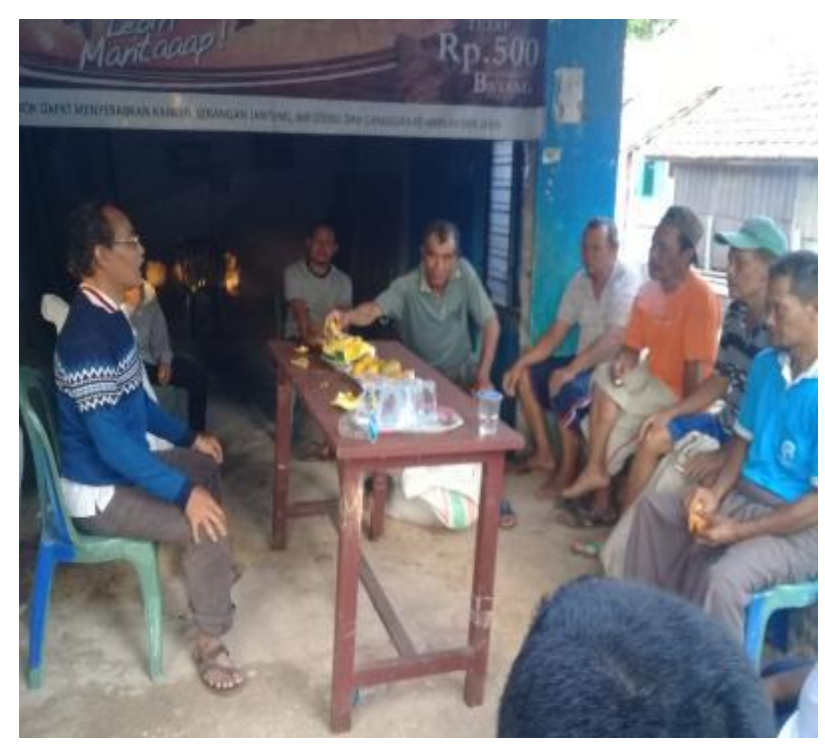

Gambar 2. Penyuluhan Sapta usaha peternakan

Tahap kedua adalah pelatihan fermentasi pakan, bertujuan untuk meningkatkan kualitas dan kandungan nutrisi pakan sekaligus menambah palatabilitas pakan bagi kambing, hal ini disebabkan aroma produk fermentasi harum yang khas disengani ternak. Pelaksanaan fermentasi menggunakan starter Inokulan super produksi Fakultas Peternakan Unisma dengan dosis 1 liter inokulan untuk 1 kuwintal bahan pakan diinkubasikan secara anaerob selama 4-5 hari dengan kelembaban udara atau kadar air bahan berkisar 45\% sampai 50\%. Bahan limbah yang difermentasi meliputi bekatul kasar, ampas kecap, ampas tahu, mineral kalsium dan limbah kulit daging kelapa sebagai pengganti bungkil 
kelapa dengan formulasi masing-masing bahan pakan sebagai berikut: 35\% bekatul : 13\% ampas kecap : $15 \%$ ampas tahu, 2\% campuran mineral kalsium dan garam : $35 \%$ kulit daging kulit kelapa bentuk kering, kemudian produk fermentasi ini diberikan pada kambing sebagai substitusi konsentrat pabrik dan diberikan sebanyak 2,5\% bobot badan kambing. Tahap awal fermentasi pakan adalah mencampur bahan pakan yang penggunaannya sedikit, kemudian dicampurkan pada bahan yang penggunaan dalam jumlah besar, diaduk sampai diyakini campuran menjadi homogen. Selanjutnya campuran bahan tersebut disiram dengan larutan starter inokulan super sesuai dosis sebanyak 1 liter inokulan per 1 kuintal bahan, teknisnya inokulan super diencerkan dengan air sampai diperkirakan campuran bahan yang difermentasi menjadi kelembaban 45-50\% yang ditandai kondisi mamel. Setelah bahan-bahan diaduk dibolak-balik sampai tercampur merata, kemudian dimasukkan dalam drum plastik dan karung zak rangkap dimampatkan sampai tidak ada cela dan tidak berongga dan ditutup rapat.

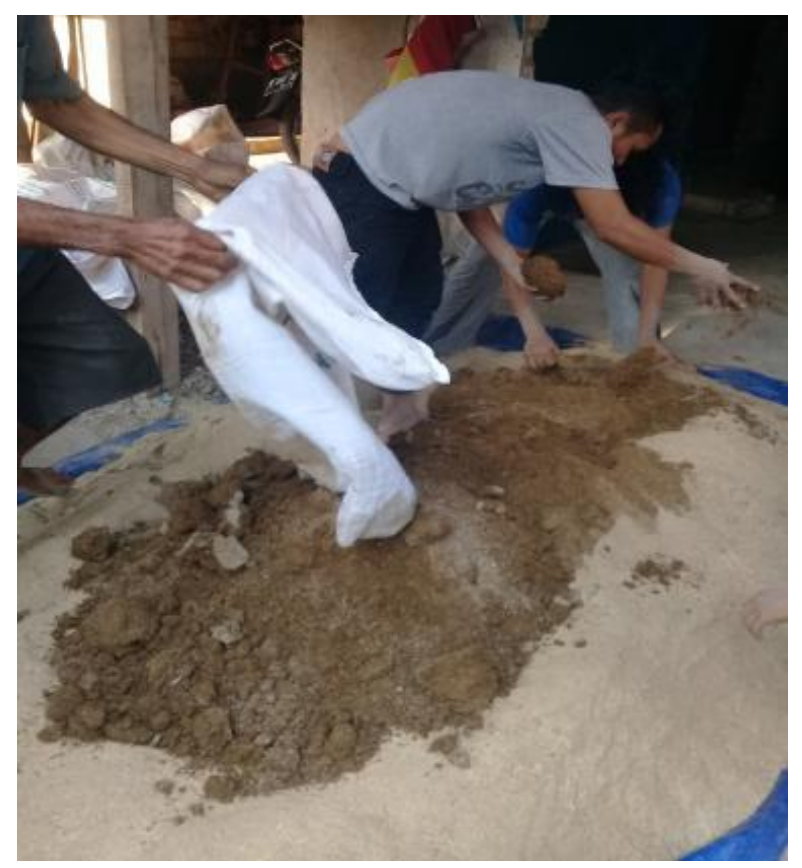

Gambar 3. Fermentasi pakan kambing

Kegiatan ketiga reboisasi lingkungan sekitar kandang perlu dihijaukan dengan ditanami pohon nangka, dan pisang sehingga nantinya kandang tidak gersang dan udara terasa segar dari fotosintesa tanaman serta tambahan buah pangan .Selain itu, perlu dilakukan reboisasi di lahan pertanian dengan sistem tiga strata (STS) dan dilakukan secara bergilir menggunakan tanaman pangan seperti jagung, kacang tanah, ubi kayu dan padi gogo di lahan kerin tadah hujan, tanaman pohon nangka, gamal dan kaliandra sebagai pagar dan rumput disisi lainnya, maka selain menghasilkan produk pokok dan buah, maka reboisasi ini bermanfaat menjadikan udara sehat, segar, asri dan naungan dari panas matahari siang hari. Tujuan utama dilakukan reboisasi tanaman pangan di lahan pertanian dengan sistem tiga strata (STS) dan secara bergilir akan membuat tanah lebih produktif dan unsur hara dalam tanah tidak terkuras habis, menciptakan kondisi lingkungan hijau berudara sehat, segar dan asri serta sekaligus peternak mendapatkan tambahan hasil panen tanaman pangan yang bisa dijual mendatangkan penghasilan. Kegiatan reboisasi dalam program PKM ini yaitu penanaman pohon nangka dan pisang di belakang kandang, dimana tanaman pohon nangka dan pisang bisa panen sepanjang tahun.

\section{ULASAN KARYA}

Pembinaan peternakan kambing ini dilakukan meliputi kegiatan penyuluhan dan pelatihan pembuatan pakan konsentrat. Kegiatan penyuluhan dilakukan sebelum pelatihan fermentasi berbagai limbah agroindustri menjadi pakan konsentrat yang bergizi dan disukai kambing, kemudian di akhir program PKM ini dilakukan pendampingan usaha selama dua minggu. Penyuluhan sapta usaha peternakan meliputi tujuh komponen yang menunjang keberhasilan usaha peternakan yang utama meliputi seleksi dan penggunaan bibit, bakalan dan indukan yang baik, pemberian pakan yang bergizi dan mencukupi kebutuhan nutrisi baik protein dan energinya, manajemen perkandangan dan pemeliharaan yang baik, manajemen perkembangbiakan dan perkawian yang tepat, perncegahan dan penanganan penyakit dengan benar, penanganan panen dan sistem pemasaran. 
Penyuluhan dilakukan dengan penyampaian materi secara langsug dilanjutkan diskusi permasalahan yang dihadapi peternak dan memberikan solusi yang bisa dikerjakan peternak. Sedangkan kegiatan pelatihan pembuatan pakan konsentrat kambing, secara bersama kolektif dengan fermentasi berbagai limbah agroindustri lokal menggunakan bakteri sellulolitik secara anaerobic dan kelembaban udara 55\% menggunakan rumus M1.C1=M2.C2 $(\mathrm{M}=$ massa bahan, $\mathrm{C}=$ kadar $\mathrm{BK})$ sehingga menghasilkan pakan fermentasi limbah agroindustri kualitas baik [4]. Namun kondisi kelembaban 55\% dapat ditunjukkan menggunakan parameter kondisi mamel selanjutnya melakukan pendampingan usaha peternakan pada dua minggu terakhir dan melayani konsultasi peternakan.

\section{KESIMPULAN}

Program PKM ini dapat disimpulkan sebagai berikut:

1. Kegiatan utama yang dilakukan meliputi penyuluhan sapta usaha peternakan dan manajemen produksi, pelatihan pembuatan pakan fermentasi pakan, formulasi pakan konsentrat sesuai kebutuhan gizi kambing, bantuan mesin copper pencacah hijauan pakan dan palungan tempat pakan, bantuan pejantan pemacek yang unggul reboisasi sekitar kandang dan penanaman sistem tiga strata (STS) di lahan pertanian

2. Mitra peternak kambing merespon baik dan proaktif terhadap semua kegiatan yang dilakuan tim pengabdi baik penyuluhan, pelatihan, pembinaan dan pendampingan usaha dan konsultasi di akhir masa pelaksanaan program PKM.

3. Peternak mengaplikasikan ilmu yang didapat menuju peternakan intensif mengacu program sapta usaha peternakan menuju peternakan kambing intensif.

\section{DAMPAK DAN MANFAAT KEGIATAN}

Dampak dan manfaat kegiatan PKM ini antara lain adalah : 1). Dapat memperbaiki manajemen pemeliharaan kambing menuju peternakan kambing yang intensif yang sebelumnya secara konvensional kandang kotor, produksi rendah dan perkembangbiakannya juga rendah, 2). Peternak memahami aspek-aspek yang mempengaruhi produksi ternak dan dapat membuat pakan fermentasi dari limbah agroindustry local yang dicampur hijauan ramban, 3). Adanya peningkatan produksi dengan pertumbuhan dengan pemberian pakan yang bergizi menggunakan pakan fermentasi, dan 4). Peternak termotivasi lebih semangat untuk meningkatkan usaha peternakan dengan pendapatan dan keuntungan yang lebih besar.

\section{DAFTAR PUSTAKA}

[1] Cahyono, B. 2003. Beternak Kambing dan Domba Kanisius. Yogyakarta.

[2] Ensminger, M.E., J.E. Oldfield, and W.W. Heinemann. 1995. Feed and Nutrition. The Ensminger Publishing Company, California.

[3] Mardikanto, T. 2009. Sistem Penyuluhan Pertanian. Pusat Pengembangan Agribisnis dan Perhutanan Sosial. Sebelas Maret University Press. Surakarta.

[4] Soebarinoto,. S. Chuzaemi dan Mashudi. 1991. Ilmu Gizi Ruminansia. Universitas Brawijaya. Anima Husbandry Project Malang.

[5] Usman, A dan Wadjdi, M, 2014. Pemanfaatan Bakteri sellulolitik sekum Kelinci dengan aras konsentrasi koloni dan waktu Inkubasi untuk Fermentasi Limbah Agroindustri Lokal dalam Pakan.

\section{PENGHARGAAN}

Pengabdi mengucapkan terima kasih kepada Direktorat Jenderal Penguatan Riset dan Pengembangan Kementerian riset, teknologi, dan Pendidikan Tinggi Republik Indonesia yang telah memberi dana pengabdian kepada Masyarakat PKM ini, serta LPPM Unisma dan Dekan Fapet Unisma Malang yang memfasilitasi kegiatan PKM ini sampai selesai. 